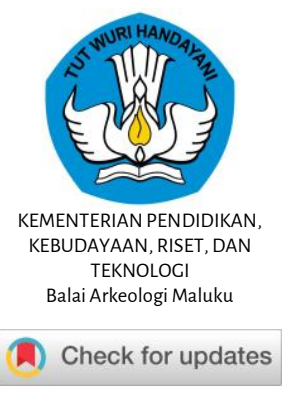

Kapata Arkeologi, 17(2) 2021, 55-70

p-ISSN: 1858-4101, e-ISSN: 2503-0876

KAPATA ARKEOLOGI

SCIENTIFIC JOURNAL OF ARCHAEOLOGY AND CULTURAL STUDIES

Accredited by the Indonesian Ministry of Research, Technology, and Higher Education (RISTEKBRIN)
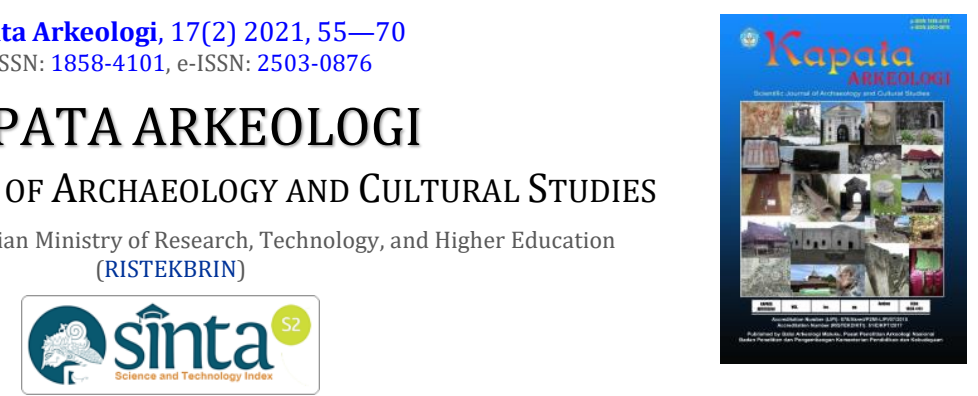

https://kapata-arkeologi.kemdikbud.go.id/

\title{
TrACING THE EARLIEST SETTLEMENTS ON SERAM ISLAND, AS A THEORETICAL FRAMEWORK FOR THE CHRONOLOGY OF HUMAN OCCUPATION IN THE MALUKu ARCHIPELAgo
}

\author{
Muhammad Al Mujabuddawat \\ Balai Arkeologi Maluku \\ Jl. Namalatu-Latuhalat, Ambon 97118, Indonesia \\ mujab@kemdikbud.go.id
}

Received: 14/09/2020; revisions: 02/11/2020 - 12/05/2021; accepted: 20/06/2021

\begin{abstract}
Seram Island is the largest island in the Southern part of the Maluku Archipelago. Geological studies also generally conclude that Seram is one of the oldest islands in Maluku. The oral tradition of the indigenous people of Maluku knows Seram Island as 'Nusa Ina' or 'Mother Island.' Seram Island is the location of the legend of 'Nunusaku' or the origins of the Maluku People. Several historical studies by experts record various archaeological data scattered on Seram Island as evidence of early human dwellings and settlements. Archaeological data on Seram Island is quite varied from the Paleolithic Neolithic to historical periods. The data shows Seram Island as the most comprehensive location of periodization of human occupation. Information on oral traditions and community reports are relatively being a reference in tracing archaeological data in some areas indicated as ancient dwellings and settlements. This study describes the traces of the earliest dwellings and settlements on Seram Island and the Southern Maluku Islands in general. The archaeological data was collected through field observations. The analysis of this study used a qualitative descriptive method on all archaeological data and information on oral traditions collected by referring to relevant reference studies. This research discusses several references of early dwellings and settlements in the pre-colonial period that have been initiated so far and the latest archaeological data based on information on oral traditions and community reports. This study also aims to summarize and review a number of the most recent references to the theory of the earliest settlement of the Maluku Archipelago, which so far is still an interesting discussion, considering the lack of archaeological data references and absolute chronology tests in this region. This research delivers a reconstruction of the theory of the earliest dwellings and settlements on Seram Island and the Maluku Archipelago in general.
\end{abstract}

Keywords: Nusa Ina; Nunusaku; Manusela; Australomelanesid; Austronesia; ancient settlement; Seram Island

\section{INTRODUCTION}

The narrative that is developed among the indigenous people of Maluku regarding the origins and the earliest life of the Maluku people cannot be separated from the term 'Nusa Ina.' Nusa Ina, or literally Mother Island is a term that refers to the land of origin of the Maluku people. Native people of Maluku are related to Buru Island, Seram Island, Ambon Lease Islands, Banda Island, to the Aru Islands, Kei, Tanimbar, and Southwest Maluku Islands. Fact tracing based on oral tradition is one of the beginnings of engaging narratives about tracing archaeological data of ancient settlements and dwellings. Sahusilawane (2005) revealed that based on the oral tradition of Seram Island has a long and oldest history in Maluku. Still, it isn't easy to write it down in the framework of scientific information. The native on Seram Island do not have written sources, and all historical information comes from narratives that are often convoluted (Sahusilawane, 2005: 44). Several academic attempts to search for data regarding the location of the earliest life and settlements of the Maluku people almost always refer to the search for the place of 'Nusa Ina,' which is firmly attached and narrated in many oral traditions indigenous Maluku people from generation to generation. Most Maluku people often mention Nusa Ina for Seram Island. This term refers to most of the oral traditions of local communities in Maluku that recognize Seram Island as the land of origin for most people in the Maluku Archipelago, especially those currently living in the Seram Island area and the Ambon Lease Islands.

In a publication entitled 'Felsbilder auf Ceram, Röder (1938) initiated a prehistoric study on Seram Island. Based on the expedition's records carried out in 1930, 
Röder (1938) recorded several locations of the rock art site in the Saleman Bay area, the North coast of Seram Island. The discovery of a rock art site on Seram Island confirms the archaeological narrative of Seram Island, known as Nusa Ina. Geological studies also generally conclude that Seram is one of the oldest islands in the geological age in the Maluku Archipelago (Ririmasse, 2016a: 126). Ririmasse (2016a: 126) reveals, based on his observations, that the landscape of Seram Island is much more complex than almost all other islands in Maluku, including several other nearby large islands such as Buru Island. So naturally, Seram is then culturally accepted as an 'old house' for the people of the Maluku Islands (Ririmasse, 2016a: 126). Seram is often an exciting destination for academic studies as a geographically strategic and culturally rich island, including archeology and cultural history. This study is more devoted to tracing early human settlements in the pre-colonial period.

The historiography of the Maluku region, which has been widely published, is mostly from the colonial period. This is because the history of Maluku is mostly built through researching documents during the colonial period. Historical references of the pre-colonial period were minimal because the data needed to reconstruct it must be archaeological data. The non-literate Maluku people only had oral traditions as historical transmitters (Darman, 2017: 135). Oral traditions are transmitted by word of mouth, giving rise to many versions (Duija, 2005: 113). The perception of the results of historical studies put forward by Maluku historians so far tends to be debatable. Oral traditions containing historical events generally include mythology and symbols that hold particular meanings (Anton \& Marwati, 2015; Endraswara, 2013; Sedyawati, 1996). The density of customs and traditions that are pretty inherent among local communities creates a tendency for historical bias to claim each other among the community in Maluku. Departing from this issue, it is necessary to have references that come from the point of view of archaeological data to strengthen historical references, especially to reconstruct the original history and culture of the Maluku people in the pre-colonial period, which did not have written evidence data.

Searching data based on oral tradition is the beginning of building a factual narrative regarding the search for archaeological data related to ancient dwellings and settlements, especially in developing academic narratives about the earliest settlements of the Maluku people. The indigenous people of Seram Island believe that the first human settlements were on Seram Island and then spread throughout Maluku Archipelago, especially the Ambon Lease Islands. This belief is well maintained by local customs and culture and several areas with a common agreement and understanding in interpreting oral traditions, although in different administrative regions.

This study aims to trace the earliest dwellings and settlements on Seram Island and the Southern Maluku Archipelago in general based on information on oral traditions and archaeological data. The earliest dwellings and settlements in this study are part of the traces of human remains during the early occupation of the Maluku Islands. This study discusses several tracing histories of early dwellings and settlements in the precolonial period that have been initiated so far and efforts

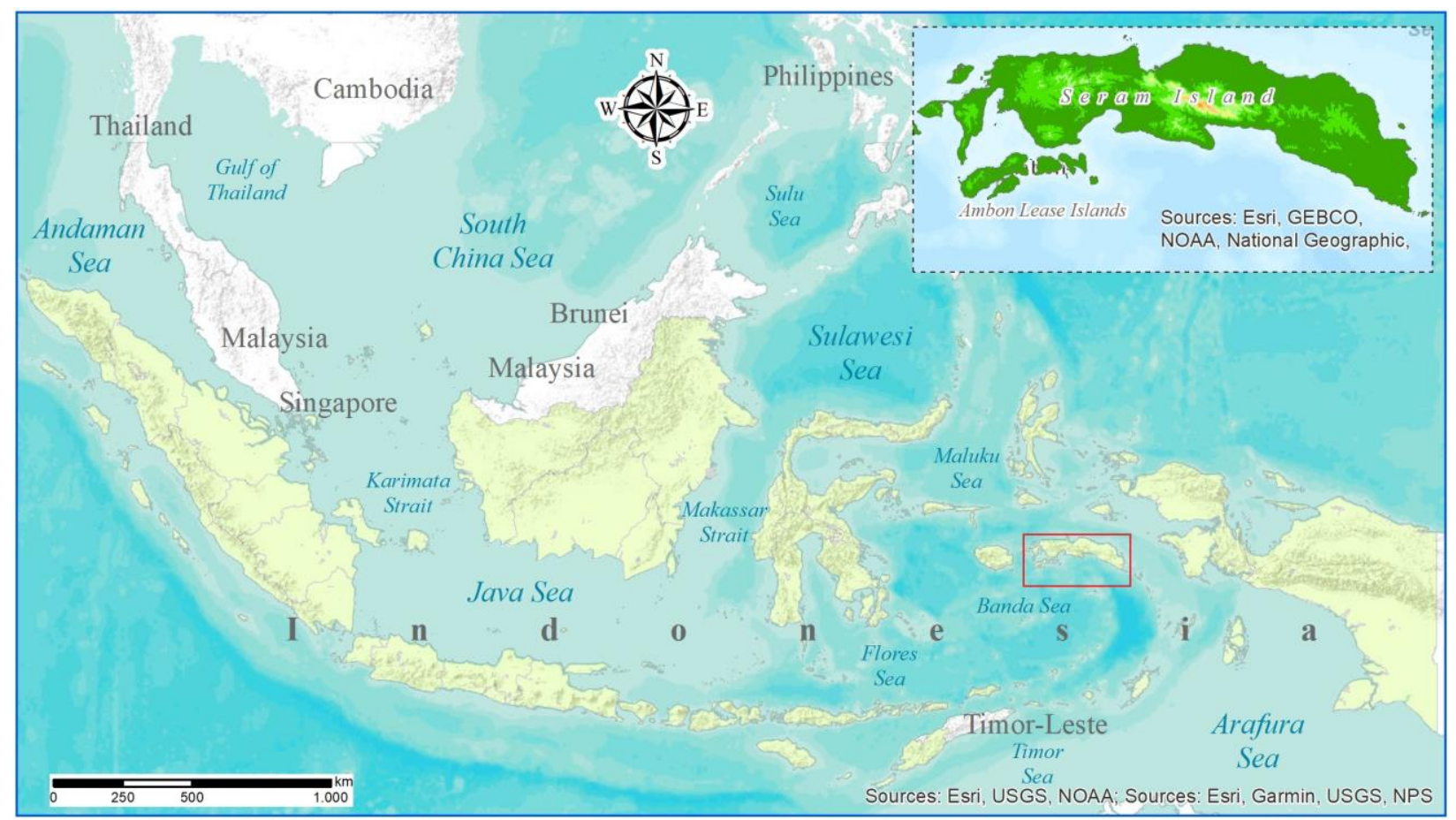

Figure 1. Location of Seram Island on the Map of the Indonesian Archipelago

(Source: ArcGIS Database, 2019) 


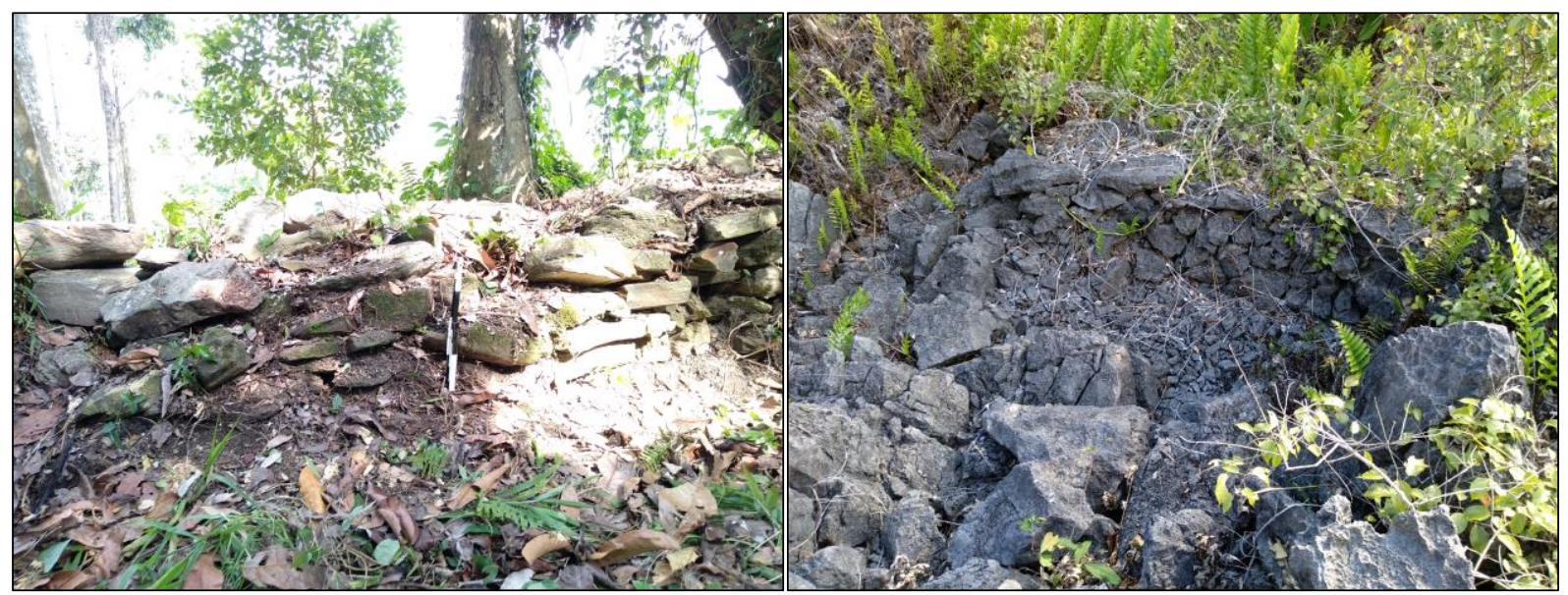

Figure 2. Stone fences (lutur) or stone structures in ancient settlements/Negeri Lama Lokki (left) and Asaude (right)

(Source: Mujabuddawat, 2018)

to search for the latest archaeological data based on information on oral traditions and community reports. This study also aims to summarize and review a number of the most recent references to the theory of the earliest settlement of the Maluku Archipelago, which so far is still an interesting discussion, given the lack of archaeological data references and absolute chronology tests in this region.

\section{METHODS}

This research was initiated based on community reports regarding locations indicating ancient precolonial settlements. This research begins with a literature search related to the history of previous research and the preparation of research designs. Archeological data collection was carried out through field observation methods at locations indicated as ancient settlements and searching for information on the oral traditions of the local community. The analysis of this study used a qualitative descriptive method on all archaeological data and information on oral traditions obtained. This research uses the literature study method to reconstruct the theory regarding various narratives of the earliest occupations and settlements of human communities in the Maluku Archipelago. The literature study collects multiple references that are up-to-date and relevant to the data found in the field.

\section{RESULT AND DISCUSSION}

Wattimena \& Handoko (2012: 52) explain that during the pre-colonial period, settlements in the Ambon Lease Islands were built in the mountains or on ridges and then shifted to the coast after the colonial period. It is estimated that the oldest human settlements in Ambon Lease are from the Neolithic period to the early colonial period. The old settlements in Ambon Lease are generally located on hills, and the Maluku people call it Negeri Lama, which is the village of the ancestors (Mansyur, 2016: 175). Negeri Lama is spread in almost all villages or Negeri (a term spoken by the people of Maluku) on Seram Island and the Ambon Lease Islands.

The ancient settlements in Maluku or Negeri Lama are generally located on hills or mountains. The existence of the Negeri Lama is identical to the historical record in the colonial period, even though the older ancient settlements were in the form of natural dwellings such as alcoves and caves (Latinis \& Stark, 2005: 127). The traditional Maluku economic system is generally divided into the coastal and arboreal economic systems. Traditional communities in Maluku, including Seram Island's hinterland, still survive in an arboreal way or live by utilizing natural sources with local geniuses in understanding environmental balance and sustainability (Latinis, 2015: 44). Based on the publications of Latinis \& Stark (2005: 130), several caves scattered in Maluku contain indications of archaeological data in the form of artefactual data such as the findings of pottery fragments and ceramic fragments, as well as the function of caves as objects of habitation and burial (see also Kealy, Wattimena, \& O'Connor, 2018; Ririmasse, 2016b; Spriggs, 1990). The function of the cave as a shelter comes from the earliest human population that occupied the East region of Southeast Asia since 40,000 years ago and developed into a community that settled by living arboreal (Latinis, 2015: 47).

\section{Record History of Research Exploration the Earliest Dwellings and Settlements on Seram Island}

The earliest research related to the search for ancient settlements or Negeri Lama in the Maluku region, especially Seram Island and Ambon Lease in archaeological and ethnographic perspectives, was initiated by Spriggs \& Miller (1988) and Spriggs (1990). They identified several cave dwellings on Seram Island and Ambon Lease, one of which is a cave complex in Hatuhuran, West Seram, followed by joint research between the University of Hawaii and the University of Pattimura (Latinis \& Stark, 2005; Stark \& Latinis, 1992, 


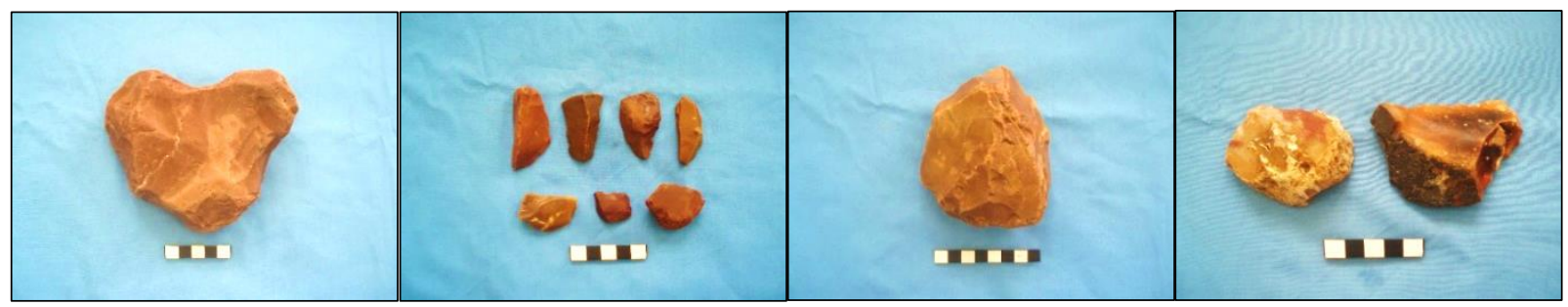

Figure 3. Paleolithic stone artifacts found in watersheds along the northern coast of Seram Island, from left to right: sizeable curved scraper, flakes, chopper, curved cutting edge chopper

(Source: Jatmiko \& Mujabuddawat, 2016)

1996). One of the earliest data retrieval locations initiated by the Balai Arkeologi (Archaeology Research Office) regarding the discovery of artifactual data and features characterized by megalithic traditions was in the Manusela Mountains range area, Maraina Village (Ririmasse, 2006).

Röder (1938) conducted an exploration along the coast of Sawai-Saleman, the Southwest Seram area around the Tala River watershed, as well as in the South and Northwest Seram areas. Based on the history of exploration of the earliest settlements in the perspective of prehistoric and pre-colonial times on Seram Island, many cave-dwelling locations were recorded. Röder (1938) documents rock art site locations in the SawaiSaleman coastal area and rock art in the Tala River watershed. Soegondho (1994) conducted exploration in the vicinity of Amahai District and found a location indicated as a dwelling cave, namely Hoapinalo Cave. Indications of cave dwellings are based on data finding such as pottery fragments decorated with tumpal, geometric, and meander motifs, and many ceramic fragments and pieces of mollusk shells. Handoko (2006) wrote that the Balai Arkeologi Ambon had further exploration in Tamilouw Village, Amahai District. The exploration result finds several data indicating cave dwellings in Tanah Merah Cave, Hakon Cave, and Hoapinalo Cave. In general, the location of these caves is a dwelling cave that was inhabited for a long time. Hoapinalo Cave is probably inhabited from the Neolithic period until around the $15-17$ th centuries. This chronological assumption is based on indications of the findings of pottery fragments characterized by the Neolithic period and ceramic fragments known to have originated from the Ming Dynasty period of the 15th17th centuries (Handoko, 2006: 27).
Tracing the earliest settlements on the mainland of Seram Island has been initiated several times. One of the earliest attempts was to search for the location of the Negeri Lama or ancient settlement at the foot of Mount Murkele, Manusela Mountains, namely Maraina Village. Ririmasse (2006) recorded several findings, such as megalithic features and a polished stone ax and transcribing kapata (verse poetry) from local communities. Handoko (2007b) documented the results of his attempts to search for archaeological data in Negeri Sahulau and Elpaputih. This attempt is based on a local legend that is quite well known in the Maluku people as part of the earliest settlements that became the descendants of today's Maluku society. However, based on the archaeological data found, it is not enough to support the facts on the legends told by the people's oral tradition. This is because feature and artifactual data findings were more associated with the colonial period.

One of the locations that contain indications of sustainable dwelling sites from the neolithic period to the late pre-colonial period is the Hatusua Site Area. Focused and intensive research by the Balai Arkeologi Maluku in the Hatusua area, West Seram Regency has been done three times in 2012, 2014, and 2015. Based on the data found, in general, the Hatusua area is a relatively complete location representing a rather long period of occupancy, starting from the use of caves as limited natural dwellings to the coverage of communities that inhabit one area.

Ririmasse (2016a) published the latest research in the Hatusua area. Twenty-two locations in Hatusua that focused on the karst area were successfully recorded. Several locations contain a variety of archaeological data, including stone tools, pottery fragments, ceramic fragments, pieces of bone, teeth, mollusk shells, and

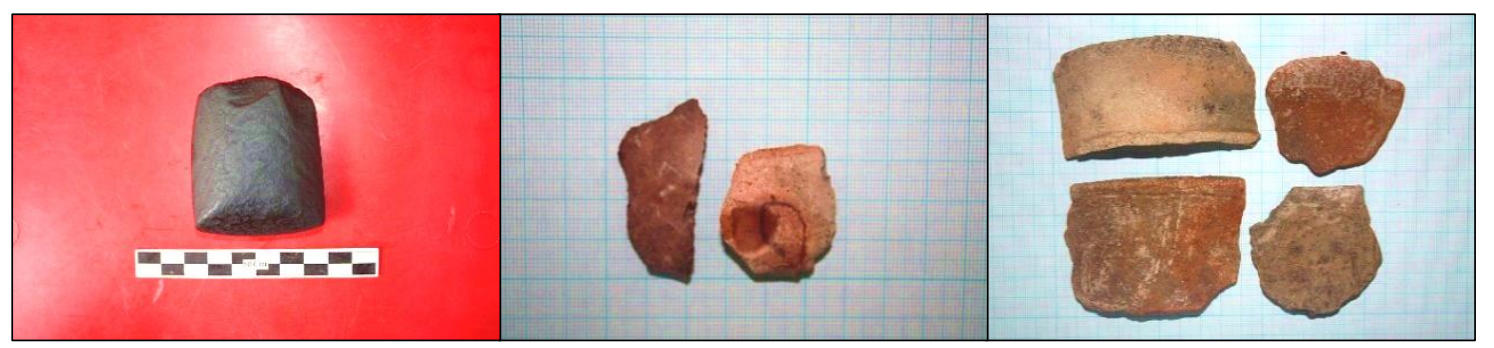

Figure 4. Artifactual data from several Cave locations in Wahai, from left to right: polished stone ax, flakes, and pottery fragments

(Source: Ririmasse \& Handoko, 2009) 


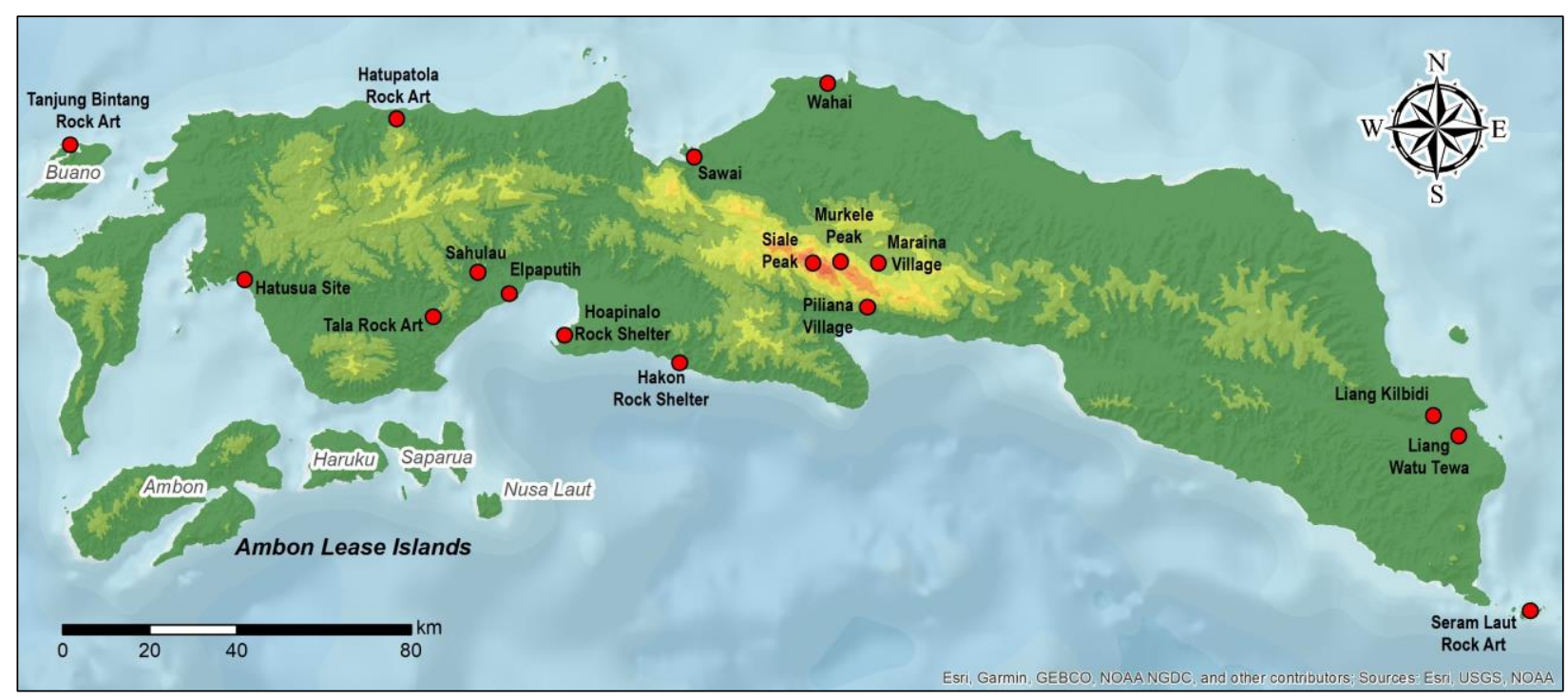

Figure 5. Reference of the earliest dwellings and settlement search locations on Seram Island

(Source: References from various sources, base map ArcGIS Database, 2019)

pieces of metal. Ririmasse (2016a) wrote a history of research and excavations in two locations thought to be human habitation caves. The first excavation was carried out in 2012 at a cave or niche called the HTS- 6 Site, and the second excavations at a cave or niche called the HTS18 Site in 2014, and continued in 2015 (Ririmasse, 2016a: 130-131). Based on the radiocarbon laboratory tests from the direct AMS method on several charcoal samples taken at the HTS-18 Site, chronological information shows $\pm 500 \mathrm{BP}-1,100 \mathrm{BP}$. The dating results congruent with absolute dating conducted by Latinis \& Stark (2005) ranged between 800-1,000 BP.

In addition, Lape et al. (2017) released a publication showing the dating of marine shell samples at a rock shelter located in East Seram. Rock shelters named Liang Kilbidi, Liang Watu Tewa, and Liang Fanga 2 are estimated to be $3,607,4,086$, and 4,850 years. These numbers were calibrated by Kaharudin, Alifah, Ramadhan, \& Kealy (2020), resulting in an age range between 5,135 BP to 3,186 BP.

\section{Tracing the Oral Tradition of the Indigenous People of Seram Island}

\section{Seram Island as the Locus of the Main Framework for the Theory of the Origin of the Maluku People}

Regarding the location of Seram Island, which is called Nusa Ina, in an attempt to find the earliest settlements, it cannot be separated from the oral tradition of the Maluku community who know the legend of 'Nunusaku.' Nunusaku or known as the holy land as the center of the earth which is believed to be the first location that the origin of descended native people to the Maluku Archipelago, that is the Alifuru Tribe.

In various versions of oral tradition narratives, Sahusilawane (2005) explains in scientific descriptions that the origins of Patasiwa and Patalima are related to expansion and political hegemony on the impact of the division of territory between the Ternate and Tidore Sultanates in the past. An attempt to search data to be used as factual references regarding the existence of Nunusaku which is associated with the theme of one of the earliest settlements and has an influence on the sustainability of civilization of indigenous communities on Seram Island and its surroundings can be drawn from the instructions of oral tradition. Several data on oral traditions that explain the existence of settlements well known to the majority of the people of Seram Island can be the primary reference. Many oral tradition information obtained yielded some clues, but the strongest indications refer to the central part of Seram Island.

\section{Information on Ancient Settlements in the Manusela Mountains}

This tracing is based on the local community's oral tradition, which states the existence of the first human settlement called Nunusaku. It is located in the Manusela Mountains range, Manusela National Park Area, Seram Island, specifically at the peak of Mount Murkele at an altitude of 2755 meters above sea level (masl) and Mount Siale or Peak 3035 masl. Ancient settlements in the highlands above an altitude of 1000 meters above sea level have never been found before in the Maluku region. This is due to the geographical landscape of the Maluku Archipelago, which consists of small islands, and only Seram Island, which has a highland geographical landscape up to an altitude of 3000 meters above sea level. Geographical conditions and extreme weather in the highlands of Seram Island result in limited choices of food sources for consumption and tend to be isolated from interaction with the broader community.

This search attempt was initiated by reports from many people and mountaineers who reported ancient 
settlements in the Manusela Mountains. Based on these reports, the Balai Arkeologi Maluku obtained information about ancient settlements located in Peak 3035. The indications are based on findings and direct observations by people who hiked to that location. Some indications of ancient settlements that have been observed and reported include several stone structures or structures that form a wall to resemble a building. In addition, the community also describes that dozens of stones have a shape resembling a seat that appears to be placed in a particular pattern. Several reports interpret the shape of the building differently, including domeshaped, cube-shaped, fortified, and various interpretations of other building forms.

\section{Tracing Ancient Settlements in the Manusela Mountains}

Manusela is a mountain range extending from North to South; in a geographical landscape, it appears to divide Central Maluku Regency. This mountain range is mainly included in the Manusela National Park area, and there are several high points or mountain peaks in this mountain range. The mountain peaks that are well known in general and are sacred by local people in the Manusela Mountain range include Binaiya Peak (3027 masl), Siale Peak/Peak 3035 (3035 masl), Murkele Peak (2755 masl), and Maraina Peak (2640 masl). Based on the results of tracing the community's oral traditions, it is known that
Siale Peak and Murkele Peak are believed to be the locations of the earliest ancient settlements inhabited by native Maluku people. In addition, based on the observation conducted by the Balai Arkeologi Maluku Team in 2006, there are several indications of archaeological evidence. The evidence was found in remains of the megalithic tradition at Maraina Village (Ririmasse, 2006).

Several reports from the public and mountaineers who have arrived at Siale Peak (3035 masl) say indications of archaeological data in the form of many rock feature objects that resemble buildings, forts, and other features of things. Based on the information obtained, the initial indication of the possibility of Peak 3035 is the location of ancient settlements. However, a direct search is needed to obtain related proof that can be recorded to support further analysis to accept scientific evidence.

\section{Indications Analysis of Ancient Settlements at Siale Peak, Manusela Mountains}

Regarding indications of ancient settlements at Siale Peak, based on several reports from the community and mountaineering communities who gave their witness about objects that indicate data on archaeological features, of course, it cannot necessarily be ignored. A number of these reports cannot be declared factual or disproved as long as there is no analysis based on the data

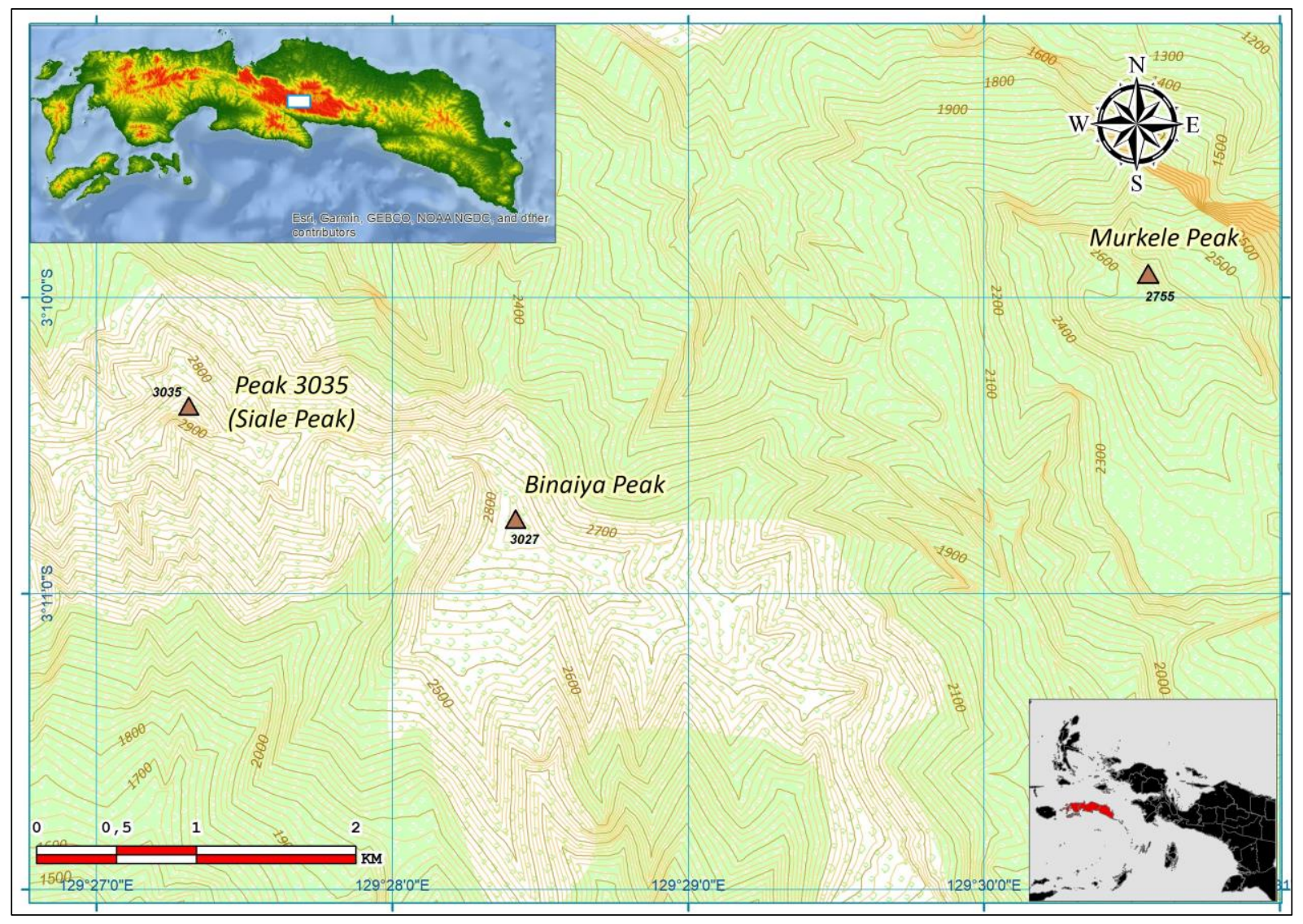

Figure 6. Map Location of Peak 3035, Binaiya Peak, and Mount Murkele (Source: Mujabuddawat, 2020) 


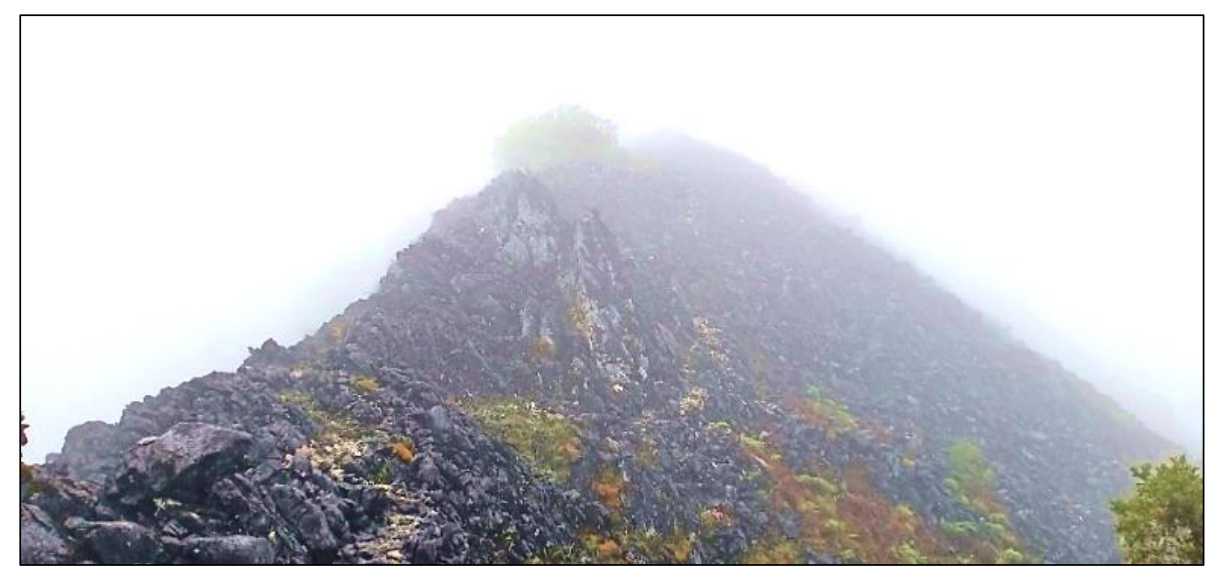

Figure 7. Epikarst profile of the Manusela Mountains at an altitude above 2500 masl

(Source: Mujabuddawat, 2019a)

obtained according to a systematic observation to be scientifically proven and accepted academically.

Most of the sites and objects of archaeological remains in Maluku were found based on reports and information from the community (Handoko, 2007a). The oral tradition data was obtained directly based on the narratives of local people in Piliana Village and its surroundings around the foot of the Manusela Mountains. In general, it is said that Peak 3035 or Siale Peak was initially believed to be meeting locations for various communities living around the Manusela Mountains. The Siale Peak developed into a settlement, and in the following period, the Siale Peak settlement was abandoned by the previous community who chose to move to lower land. In the absence of archaeological data that can be analyzed and proven, this analysis can only be based on the realm of theoretical review and comparison of similar indications in several places.

People reported indications of archaeological feature objects suspected of being tables, stone chairs, fortification structures, and dome buildings. By eyesight, examining the information, and photo data reported, several indications appear limited to natural exokarst rock formations. By changing points of view, theoretical analysis can be continued more deeply, focused not only on considering the object as a natural formation but also as an object formed naturally but is utilized and used in human activities.

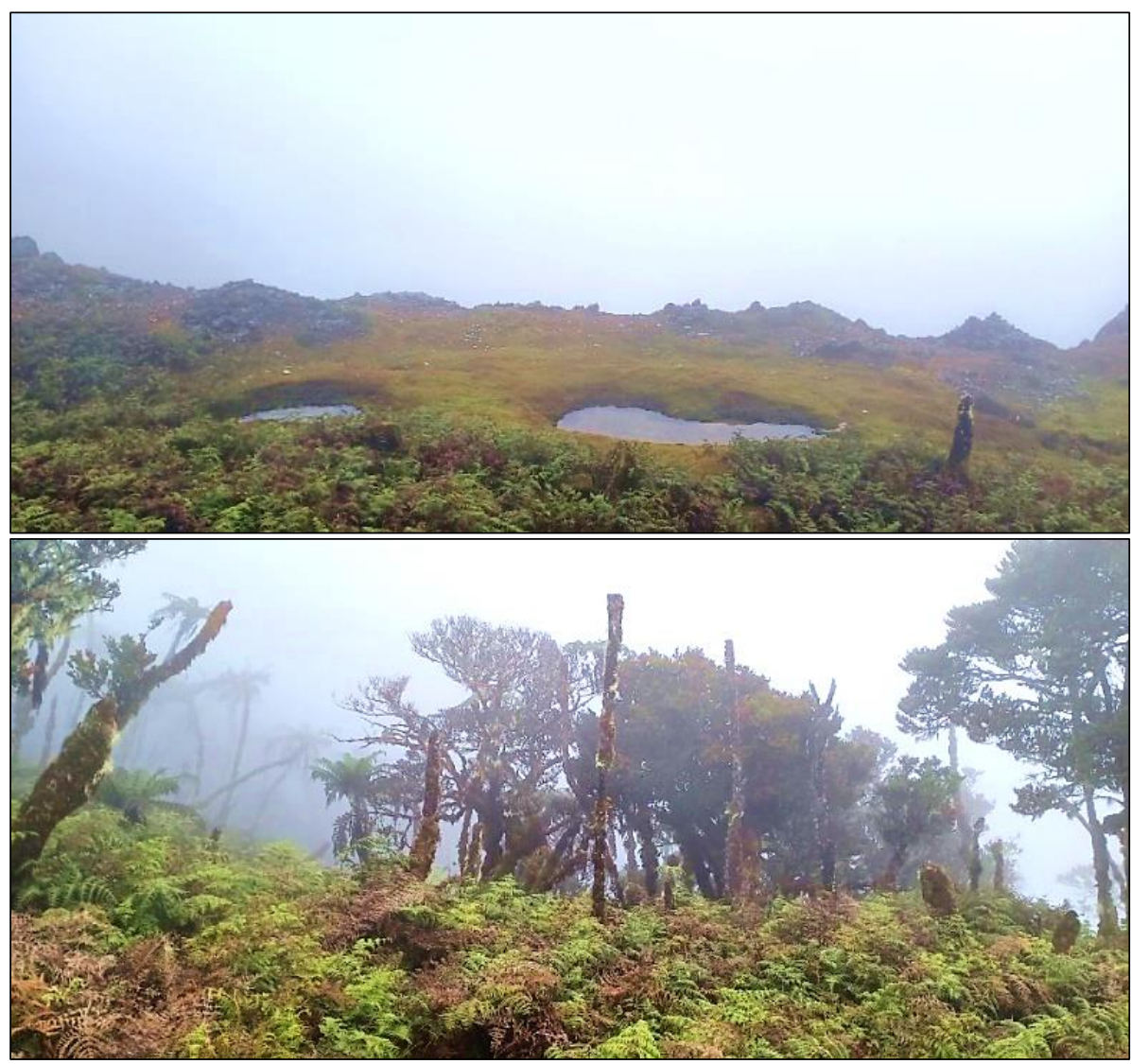

Figure 8. The landscape of the valley area on the path to Siale Peak (3035 masl) is a habitat for wild deer (Source: Mujabuddawat, 2019a) 
Indications analysis of the artifactual data findings refers to many published references, related to megalithic traditions and early ancient settlements during the hunting and gathering period in prehistoric times in the Seram Island and Ambon Lease Islands. Findings of natural objects used in human activities or are part of the use as settlement areas can be compared with several sites with similar indications. What makes the difference is the finding of artifactual data at site locations that have contextual relevance and evidence that supports the analysis (see references Mansyur, 2016; Mujabuddawat, 2018; Mundarjito, 1993; Ririmasse, 2006, 2010; Sudarmika \& Handoko, 2007; Triwuryani, 1995; Wattimena, 2016b, 2016a). The finding of artifactual data is the strongest indication that supports the analysis of human activities until further investigation is related to aspects related to the spatial context, distribution, to settlement patterns (Clarke, 1977). This artifactual data is essential evidence that has not been successfully obtained from the search to the Siale Peak (3035 masl).

\section{Analysis of the Earliest Settlement Traces Based on Archaeological Data Records}

\section{Maluku Archipelago Early Crossing Period,} Connecting between the Sunda and the Sahul

Several general theories that experts have published indicate that the earliest human occupation in the Maluku Archipelago was along the coastal area, primarily inhabiting many natural formations in the form of niches and caves in coastal karst areas (Heekeren, 1972; Intan
\& Istari, 1996; Mansyur, 2007; Sugiyanto, 2006), due to the process of cultural distribution and human migration by sea (Nurani, 2000; Olson, 2004; Simanjuntak, 1997, 2000). Data on oral traditions regarding the origin of the Maluku people on Seram Island are temporarily ignored by referring to data on archaeological objects used as a basis in reconstructing answers related to the earliest human arrival on Seram Island, or the Maluku Archipelago in general. Based on the reconstruction of the migration path based on the paleogeographic modeling proposed by Kealy, Louys, et al. (2018), human communities may have arrived in the Maluku Archipelago since at least 65,000 years ago Clarkson et al. (2017). However, no evidence of archaeological data has been found that can confirm the chronology of this period. So, the possibility that can be drawn based on archaeological data found in the Maluku Archipelago is the arrival of a migration wave at a younger time period.

Based on the reference published by Birdsell (1977), in general, the diversity of archaeological remains on Seram Island can pay attention to the analysis of human migration paths. The theory that has been agreed so far is that the path of human migration in the Maluku Archipelago is divided into two directions: from Mangoli Island towards the North to the Northern and Eastward to the Southern part of the Maluku Archipelago. The archaeological record shows that the artifactual data found at the Gola Cave Site, Halmahera, North Maluku Islands is around 30,000 years old, or the same age as the artifactual data found at the Liang Lembudu and Nabulei Lisa sites in the Aru Islands (Mansyur, 2007; O'Connor,

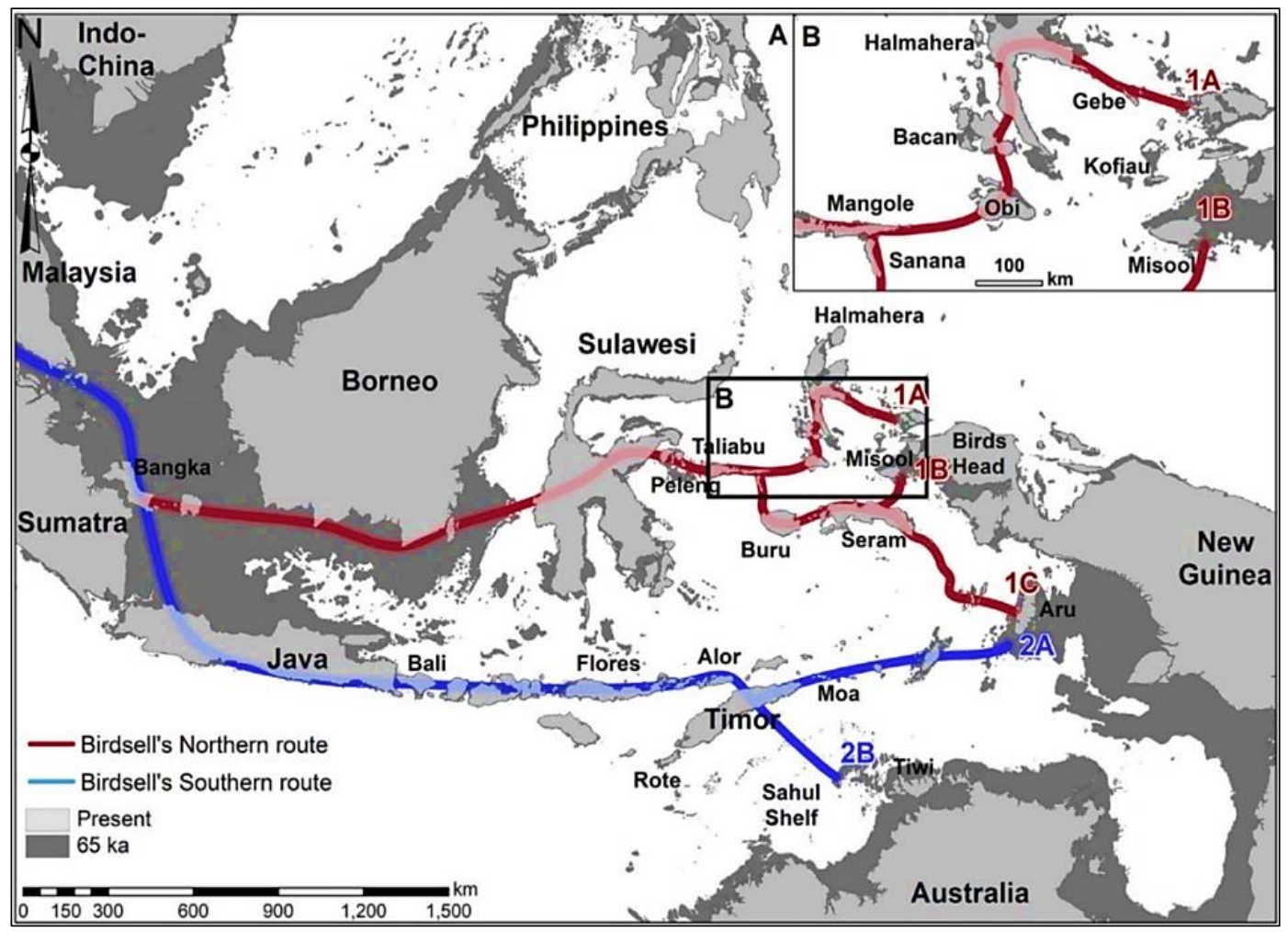

Figure 9. The migration path of the occupation of the Indonesian Archipelago based on the analysis of Birdsell, 1977 (Source: Kealy, Louys, et al., 2018) 
Spriggs, \& Veth, 2005; Veth et al., 2005). This fact is one of the primary supports for the theory of two human migration routes in the Indonesian Archipelago, the North and South routes.

The earliest human communities that inhabited the Australian mainland via the Southern route and the Papua-Pacific via the North route were Australomelanesid races. For thousands of years, they underwent separate changes and developments but still displayed the typical characteristics of their ancestors (Bellwood, 2000; Suroto, 2010). The human community that arrived in the Aru Islands continued to grow to occupied mainland Australia, while the human community that came from the Northern route arrived on Waigeo Island developed into the inhabitants of the mainland of Papua and continued to the East to inhabit the islands in the Pacific Ocean, including the Admiralty Islands, New Britain, New Ireland, Solomon between 35,000-13,000 years ago (Allen \& Gosden, 1992; Smith, Spriggs, \& Frankhauser, 1993; Spriggs, 1997).

In Indonesia, the general characteristics of Australomelanesid are still attached to the indigenous communities of Nusa Tenggara, Maluku, and Papua or are included in the Arafuid and Papuid sub-races (Jacob, 2008). Concerning the oral tradition regarding the term 'Nusa Ina,' based on the archaeological studies that have been published so far, it is appropriate to state that Seram Island is the starting ground for the development of the civilization of human communities associated with the areas of Seram Island, Ambon Lease Islands, Banda Islands, and Kei Islands. So, the theory regarding the existence of the earliest human community settlements most likely came from Seram Island.

Most experts agree on the reference that reveals one of the scientific evidence that indicates the earliest traces of human existence is the discovery of rock art. Rock art is also one of the most supportive references to build narratives of early human occupation and distribution pathways (Arifin, 1992; Arifin \& Delanghe, 2004; Tan, 2014; Widianto et al., 2017). The finding of rock art scattered in the Maluku Archipelago belongs to the environmental character of a group of small islands. The findings of rock art in the Maluku Archipelago almost have the same characteristics of location placement. The marker specifically, on the surface of karst rocks in cliffs and inlets on the coast. Likewise, with the findings of rock art in the Sawai-Saleman karst area on Seram Island's Northern coast, rock art is only found on the surface of cliffs and inlets on the coast. Rock art in the Sawai-Saleman karst area is known to be associated with the site environment showing an age range of 3,4143,586 cal BP (Lape et al., 2017); this data indicates that Seram Island has been visited or has been occupied by humans for more than 3,000 years. However, it is undeniable that humans have probably inhabited Seram Island even longer.

\section{Maluku Archipelago in the Neolithic Period, Arrival of Austronesian Culture}

The origins of the human community that arrived and occupied the Southern Maluku Archipelago today can still be built on various theories. The human community in this discussion is Anatomically Modern Human to represent the Homo Sapiens races. The criteria for Anatomically Modern Human may be quite complex when compared to the variety of human races in the Indonesian Archipelago today (Mujabuddawat \& Peseletehaha, 2020). The most common theory accepted by experts so far is that the Australomelanesid race is the earliest human community that crosses and occupies parts of Southeast Asia (Radiny \& Artaria, 2019).

Several theories that have emerged are the Austronesian cultural-speaking community as one of the earliest inhabitants of the Maluku Archipelago. Besides the theory of Australomelanesid migration during the glacial period around the end of the Pleistocene Epoch between 40,000 and 10,000 years ago and the Holocene Age between 10,000 and 3,000 years ago by a 'land bridge' connecting the Indonesian Archipelago with mainland Asia (Bellwood, 1991, 2007; Fauzi \& Simanjuntak, 2016; Simanjuntak, Forestier, Driwantoro, \& Jatmiko, 2006; Simanjuntak, Pojoh, \& Hisyam, 2006). In addition, theories built on paleogeographic modeling by Kealy, Louys, et al. (2018) suggest that human communities have crossed the Wallacea since 65,000 years ago. Significant progress of civilization occurred during the arrival of Austronesian culture-speaking communities in the Maluku Archipelago or the so-called Neolithic period around 4,500-3,500 BP, replacing the hunting and gathering culture Australomelanesid community. The Maluku Archipelago, which is part of the crossing path for the spread of Austronesian cultural speakers to the Melanesian to Polynesian Region, is considered to have a connection with the early emergence of Lapita cultural characteristics that are widespread in the Pacific Region (Lape, 2000). However in the meantime, this still needs to be explored further.

Based on several references, the rock art motifs at Sawai-Saleman, the North coast of Seram Island, and rock art at Ohoidertawun Site, Dudumahan, Kei Islands show the specific characteristic of typical Austronesian Painting Tradition (APT) motifs or the rock art made by Austronesian culture speakers (Leihitu \& Permana, 2019; O’Connor, Louys, Kealy, \& Mahirta, 2015). In addition to its location, Ballard (1992) suggests the placement of the rock art on the sites also shows distinctive features. All the sites mentioned above are generally located in isolated places far from the villages, 
some of the images are depicted on very high and difficult-to-reach cliff walls.

The Austronesian Painting Tradition shows several distinctive motifs: geometric, concentric circles, spirals, human face motifs, anthropomorphic motifs, handprints, sun, and boat motifs (O'Connor et al., 2015; Tanudirjo, 2011). Characteristics of the Austronesian Painting Tradition are also clearly seen in the pattern of rock art at the Hatupatola and Tanjung Bintang locations, located in the western part of the Seram Island Peninsula. Evident characteristics are anthropomorphic, geometric, sun, and circle motifs and depicted in a position that is difficult to reach on a relatively high cliff surface (Mujabuddawat, 2019a). Based on the data and references mentioned above, it clearly shows that the forerunner of civilization and culture of the human community that occupied the Maluku Archipelago started to develop rapidly since the arrival of the Austronesian culture-speaking community, or the beginning of the Neolithic period around 3,500 years ago.

Based on genealogical perspective research, it is suggested that the earliest inhabitants of the human community in the Maluku Archipelago were the Australomelanesid race or the ancestors of the Melanesian. In further research, the theory of the existence of the Mongoloid sub-race that replaced the Australomelanesid in the Indonesian Archipelago was developed, which is always associated with the arrival of

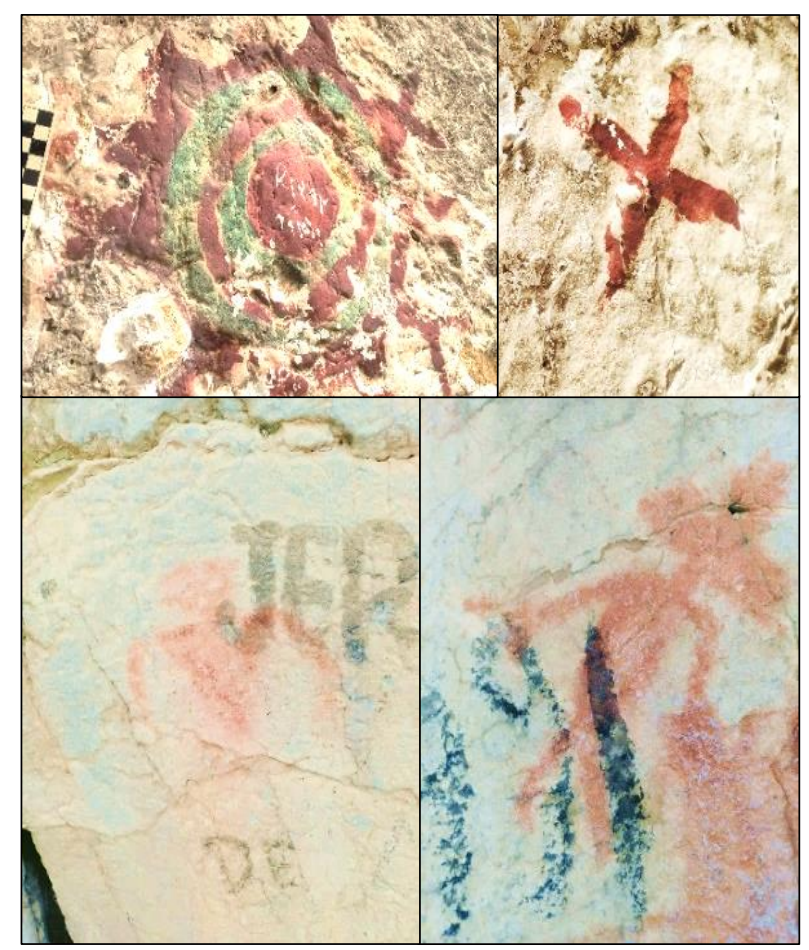

Figure 10. The typical of Austronesian Painting Tradition rock art (top to bottom): geometric and concentric circle motifs at the Tanjung Bintang, the North Coast of Buano Island, and anthropomorphic motifs at the Hatupatola Hill location, West Seram Island (Source: Mujabuddawat, 2019b; Wattimena, Nussy, et al., 2019) neolithic traditions due to the spread of Austronesian culture speakers 4,000 years ago (Widianto, 2008). The general conclusion in the Maluku Archipelago is the occurrence of cultural mixing between the ancient human community, that is, the Australomelanesid with the Austronesian. Based on factual data, so far, the neolithic tradition of the Maluku Islands is characterized by the Austronesian culture speaker.

\section{Reconstruction of the Early Settlement Theory in the Manusela Mountains, Seram Island}

Referring to the study proposed by Mundarjito (1993), ecological considerations in determining the location of human dwellings or settlements are not thoroughly influenced by climatic conditions and extreme weather. The location of the human settlements depends on several essential aspects supporting basic needs are available, including food and water sources. Weather conditions at Peak 3035 or Peak Siale (3035 masl), located in the highlands of the Manusela Mountains, tend to change from sunny to rainy conditions and vice versa quickly. Low air temperatures and winds measuring seven on the Beaufort scale or speed up to a range of 51-60 km/hour are characteristic of the weather conditions in high mountain areas, which are generally felt to be extreme. The area that includes the location of Siale Peak (3035 masl) be in the core zone area of the Manusela National Park, a habitat for a variety of natural flora and fauna ecosystems that are preserved. This shows that appropriate climatic and weather conditions support the area's biodiversity that grows and develops. In this case, extreme weather refers to aspects of subjective assessment.

Based on various studies related to the adaptability of humans to the environment, it is pretty clear that human communities in various places in the world during the emergence of the oldest civilizations managed to condition themselves from different environmental conditions such as extreme climate, weather, and topography. Several ancient human settlements are located at a high altitude of more than 3000 meters above sea level, such as in the Andean highlands of South America (William J. Schull, 1990). Adaptation to the environment impacts the stimulation of a community's behavioral traits and cultural characteristics (Wohlwill, 1974), and the human body can automatically adapt to natural conditions, both physical and genetic (Pritchard, Pickrell, \& Coop, 2010). Seram Island in the Maluku Archipelago is in the Wallacea region, located between the Huxley Line and the Weber Line (Dickerson, 1928). Wallacea includes all the islands between the Sunda Shelf and the Sahul Shelf, comprising the Lesser Sunda Islands or Nusa Tenggara, Lombok Island to the East, including Sulawesi and Maluku Philippines, and Sulu but not including Palawan (Bellwood, 2000). Examining 
from the aspect of basic human needs in the early period of human occupation on the mainland of Seram Island, the simplest human civilization was formed after the period of hunting and gathering, or the beginning of Neolithic.

The possibility suggested based on various generally accepted theories is that it is clear that the earliest human dwellings in the Maluku Archipelago was along the coast mainly inhabiting several natural formations in the form of niches and caves in the coastal karst area (Heekeren, 1972; Intan \& Istari, 1996; Mansyur, 2007; Sugiyanto, 2006). This dwelling location is due to the process of cultural distribution and human migration by sea (Nurani 2000; Olson, 2004; Simanjuntak, 1997, 2000). In subsequent developments, natural conditions influence decision-making to choose a place to live which is considered better based on considerations of food, water, security, and motivational drives to explore due to civilized thought (Butzer, 1994; Mujabuddawat, 2015). This decision-making encourages human migration to various places, one of which is the highlands such as the Manusela Mountains area. In an ideal reconstruction effort, the possibility of migration to the highland location of the Manusela Mountains was based on the presence of food sources. In this case, one of the indications is the location of the habitat of prey animals which are part of basic human knowledge in meeting the needs of life, that is, hunting and gathering activities (Simanjuntak, 2000).

Life-supporting ecosystems of various flora and fauna are available in the Manusela Mountains area, including the Siale Peak (3035 masl) in it. The existence of wildlife habitats, such as deer (Cervus timorensis moluccensis) as the main target of prey animals, can encourage human migration from coastal areas to mountainous highlands. The vegetation that grows on the Manusela Mountains range is quite varied, ranging from a rainforest in the low mountains to flourishing at an altitude of about 1000 meters above sea level. In this area, a variety of different species dominate, including 'oak trees' (Lithocarpus and Castanopsis), 'meranti' (Shorea salanica), coniferous trees, resins, or conifers (Pinophyta or Coniferae, Agathis, and Dacrydium), all covered with a thick layer of mosses and ferns. Some of the vegetation that grows along the Manusela Mountains range has benefits that can meet the needs of human life. At altitudes above 2500 masl, it is characterized by subalpine high-mountain vegetation, such as dwarf 'elfin' plants or short woody trees, and is dominated by tundra, ericaceous shrubs, and tree ferns (Bowler \& Taylor, 1989). The vegetation includes meranti trees as raw wood materials, coniferous trees as fuelwood, and ferns as a food source. The need for water sources is available at the Siale Peak location (3035 masl). Based on information and narratives from people who have set foot there, there is a water source in the form of a lake pond available with water throughout the year. The Manusela Mountains area belongs to 'very wet' criteria based on the type A climate category in the Schmid and Ferguson classification (Supriatna, 2014). Rainfall is above $2,500 \mathrm{~mm} /$ year, and the average humidity is above 82\% (Undaharta, Sutomo, Ardaka, \& Tirta, 2012: 3). Upland areas or forests in the wet mountains are good water catchment areas. Water spring discharge in the hills is generally large and continuous because it is considered the beginning of the emergence of groundwater to the surface (Hendrayana, 2013; Kodoatie, 2012). In general, the fulfillment of water needs in the Manusela Mountains is available naturally, also supported by factual findings of rainwater catchment locations that formed naturally along with the Manusela Mountains range. The topographic landscape of Siale Peak (3035 masl) in the form of a sloping and vast expanse of open fields is an ideal plain to form a living community.

Oral traditions conveyed by the community around the Manusela National Park Area, especially the people who live in traditional villages, mention the locations of ancient settlements inhabited by their ancestors in the Manusela Mountains. They believe that the toponym known as Mount Murkele in the Manusela Mountains is one of the oldest community settlements in Maluku. Also, Siale Peak (3035 masl) is a meeting place that brings together all communities living in the Manusela Mountains range area. Siale Peak (3035 masl) was once developed as a temporary settlement area, and then the entire community moved to various lower land to live. The archaeological data finding in the form of artifactual data, features, and buildings in mountainous highland areas in several locations in Indonesia is commonly found on the island of Java, contemporary with the classical Hindu-Buddhist period.

Based on several references, archaeological findings in the form of terraced buildings and the distribution of other features located on the highest plateau in Indonesia are the Mount Argopuro Site in the Iyang Mountains, East Java. The site area at an altitude between 2982-3070 masl, with the data, was found spread over a radius of more than $1 \mathrm{~km}$ (Afriono, 2011). Based on the study of shape, this terraced building characterizes the style of the Hindu terraced building during the late Majapahit era in the 15 th century. Based on the analysis of functions, it is known that the terraced building complex at the Argopuro Site functions as a karsyan or a place of meditation for the rsi (Afriono, 2011; Harisusanto, 1999; Munandar, 1992). The term rsi, which refers to the Old Javanese language, means pious, wise, and prudent (Zoetmulder, 1982). Karsyan locations are generally on high mountain peaks in the middle of the forest (Munandar, 1994). 


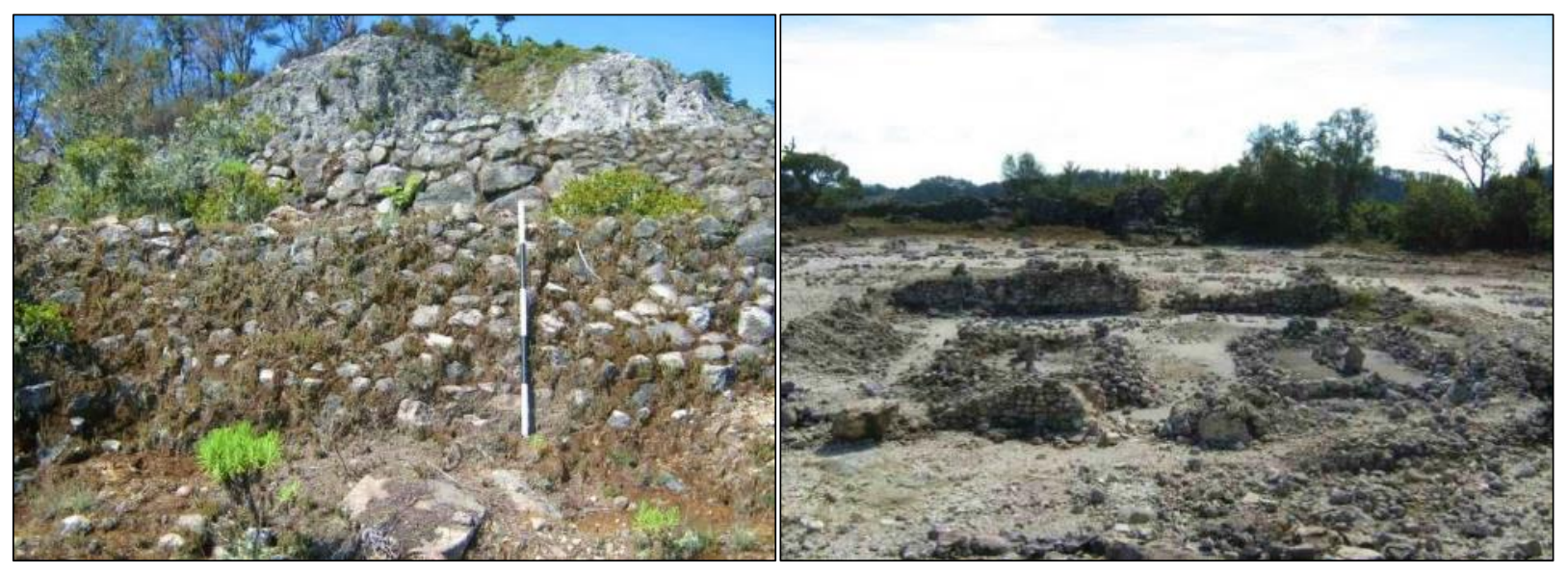

Figure 11. Archaeological features at Mount Argopuro Site, Iyang Mountains, 2982-3070 masl (Source: Afriono, 2011)

Indications of the ancient settlement of Siale Peak (3035 masl) in the highlands of the Manusela Mountains based on the narrative of the community's oral traditions are relatively in contrast to the archaeological features at several sites in the mountainous highlands of Java Island. The features and archaeological buildings in the plateau in Java Island embody a civilization that explicitly contains the intent and purpose of establishing a belief system, one of which is related to religious elements intended for certain circles, the rsi. It is different from settlements in the mountainous highlands on Seram Island, which indicates ancient settlements in Siale Peak (3035 masl). Based on oral tradition data and community information, it is relatively sufficient to explain the general description of Siale Peak (3035 masl) as a location that functions as a simple place to live based on encouragement to fulfill the needs of human life, which at that time considered to be still nomadic. However, this conclusion is still in the form of a narrative-theory without archaeological data to support it.

\section{Conclusion}

Based on the latest archaeological research, the term Nusa Ina is proper for Seram Island as the location for the growth and development of early human civilization in the Southern Maluku Islands. The human community associated with the Nusa Ina civilization is based on tracing its genealogical roots based on the theory of human migration routes. The basis of the cultural community in the Southern Maluku Archipelago is divided into two routes. The two routes are the North route culture community associated with Seram Island, Ambon Lease Islands, Banda Island, and Kei Islands, and the Southern route community associated with the Southwest Maluku Islands, Tanimbar Islands, and Aru Islands. Regarding the oral tradition of the term 'Nusa Ina,' it is appropriate to state that Seram Island is the starting ground for developing the civilization of the early human community associated with Seram Island,
Ambon Lease, Banda Islands, and Kei Islands. Hence, the earliest human community settlements theory most likely came from Seram Island.

Based on various theories that experts have suggested, one of which is through paleogeographic modeling, it is most likely that modern humans of the Australomelanesid have arrived at the Maluku Islands in the Wallacea Region between 70,000 and 65,000 years ago. The Wallacea region is in the most strategic position in uncovering the earliest crossing paths of human communities because it is a connecting area between the Sunda Shelf and the Sahul Shelf. However, this reference is not factual due to the lack of archaeological data, especially information on absolute dating tests in the Wallacea Region. Still, it can temporarily be used as an academic reference until a new theory emerges based on the latest data findings. During the Australomelanesid community in the Maluku Islands for thousands of years, there was no significant cultural development. In this early settlement period, the human community that occupied the Maluku Archipelago still lives simply in limited communities and depends on everything nature provides, fulfilling their needs by hunting and gathering. Significant cultural development began from the arrival of the Austronesian culture-speaking community in the Maluku Archipelago around 4,000 years ago. The influx of Austronesian culture had a considerable impact on the entire Australomelanesid community that had previously occupied the Maluku Archipelago. The mixing of these two human communities has encouraged the advancement of culture and civilization, including maritime knowledge, domestication of animals, agriculture, traditions, languages, pottery technology, polished stone ax, and innovations in rock art. The arrival of the Austronesian culture-speaking community gave rise to the distinctive rock art motifs known as Austronesian Painting Tradition (APT).

Based on the findings of rock art in the SawaiSaleman karst area, it is known that the relative 
chronology of the earliest human arrival and settlement on Seram Island is at least 3,000 years ago. This is also a marker of the traces of the first civilization or the start of the Neolithic period on Seram Island. This age is much younger than the data from the Southern Maluku route, including the Southwest Maluku Archipelago, Tanimbar Islands, and Aru Islands, which are associated with 30,000 years old archaeological finds, or the same as those found on Halmahera Island, North Maluku Archipelago. Reconstruction of the theory of early settlement starts from the simplest dwelling place that is limited to forming colonies based on the findings of rock art starting from the coastal karst area in the West Seram Island, including the Hatupatola and the SawaiSaleman karst area. The data in this study shows an overview of habitation development from dwelling caves around the Sawai-Saleman karst area on the North coast to several possibilities they continue to develop further towards the mainland of Seram Island. They move to inhabit many locations in the highlands, instinctively following the food source that is from the sea and the terrestrial sources. The influx of Austronesian culture encourages progress in social interaction, including social changes from small, limited to complex communities that developed to social strata and regional expansion. Although, it has not been archaeologically proven related to the people's oral tradition of Seram Island, which suggests that the earliest human settlements were on the Siale Peak (3035 masl) and Mount Murkele (2755 masl), the data on the oral tradition cannot be ignored. Based on a general theoretical reconstruction review, the Manusela Mountains are likely to be a land route for the human communities on Seram Island, connecting the sea route on the North coast to the Southside of Seram Island to the Ambon Lease Islands, which lasts for thousands of years. At least several megalithic features data were found in the highlands of the Maraina Site, the Manusela Mountains, which showed that the settlement of human communities in the highlands of Seram Island was very likely to occur.

The selection of settlement locations in relatively highland in a simple theoretical sequence cannot be separated from the intuitive function of humans seeking protection and more available resources. The habitation of highlands, mountains, and hills as human community settlements is generally adapted by most communities in the Southern Maluku Archipelago. The term Negeri Lama, which is usually located in the highlands, has generally been distinctive of settlements of the Maluku people since the Pre-colonial period. Several possibilities that underlie the selection of settlements locations in relative highlands may also be due to the history of ancient natural disasters, including the earthquake and tsunami that hit the coastal areas of the
Maluku Archipelago. The history of ancient natural disasters encouraged the indigenous people in the Maluku Archipelago to choose highland settlement locations to avoid natural disasters, such as tsunami waves. However, once again, various theories, analyses, and theory building that are currently still recognized in academic circles are not factual truths but will continue to develop and latest data based on ongoing research activities in the future.

\section{ACKNOWLEDGEMENT}

I want to thank all those who helped make this article. I am grateful to the Balai Besar Manusela National Park for granting the research permit. I also thank fellow researchers at the Balai Arkeologi Maluku and the Department of Geography at Universitas Pattimura, who have assisted during the research. I also appreciate all the assistance to all parties at Piliana Village, SawaiSaleman, Huaulu, and Buano Island. I hope this article can contribute as a reference regarding the history of Seram Island in general. 


\section{REFERENCES}

Afriono, R. (2011). Identifikasi Komponen-Komponen Bangunan Berundak Kepurbakalaan Situs Gunung Argopuro. Undergraduate Thesis Universitas Indonesia.

Allen, J., \& Gosden, J. (1992). Report of The Lapita Homeland Project. Canberra: Department of Prehistory, Research School of Pacific Studies.

Anton, \& Marwati. (2015). Ungkapan Tradisional dalam Upacara Adat Perkawinan Masyarakat Bajo Pulau Bulu Kabupaten Muna Barat. Jurnal Humanika, 3(15), 1-11.

ArcGIS Database. (2019). GEBCO 2019 Basemap (NOAA NCEI Visualization). Retrieved April 2, 2020, from ArcGIS Hub website: http://hub.arcgis.com/datasets/

Arifin, K. (1992). Lukisan Batu Karang di Indonesia: Suatu Evaluasi Hasil Penelitian. Jakarta: Lembaga Penelitian Universitas Indonesia.

Arifin, K., \& Delanghe, P. (2004). Rock art in West Papua. Paris: UNESCO Publishing.

Ballard, C. (1992). Painted Rock Art Sites in Western Melanesia: Location evidence for an 'Austronesian' tradition. In J. McDonald \& I. Haskovec (Eds.), State of the art: Regional rock art studies in Australia and Melanesia (pp. 94-106). Melbourne: Australian Rock Art Research Association.

Bellwood, P. (1991). The Austronesian Dispersal and the Origin of Languages. Scientific American, 265, 88-93.

Bellwood, P. (2000). Prasejarah Kepulauan Indo-Malaysia (D A. Tanudirjo, Anggraeni, D. Witjaksono, \& Mahirta, Eds.). Jakarta: PT Gramedia Pustaka Utama.

Bellwood, P. (2007). Prehistory of The Indo-Malaysian Archipelago (Revised). Honolulu: University of Hawaii Press.

Birdsell, J. B. (1977). The Recalibration of a Paradigm for the First Peopling of Greater Australia. In J. Allen, J. Golson, \& R. Jones (Eds.), Sunda and Sahul: Prehistoric Studies in Southeast Asia, Melanesia, and Australia (pp. 113167). London: Academic Press.

Bowler, J., \& Taylor, J. (1989). An annotated checklist of the birds of Manusela National Park, Seram (birds recorded on the Operation Raleigh Expedition). Kukila, 4(April), 3-29.

Butzer, K. W. (1994). Archaeology as Human Ecology Method and Theory for a Contextual Approach. New York: Cambridge University Press.

Clarke, D. L. (1977). Spatial Archaeology. London: Academic Press.

Clarkson, C., Jacobs, Z., Marwick, B., Fullagar, R., Wallis, L., Smith, M., ... Pardoe, C. (2017). Human Occupation of Northern Australia by 65,000 Years Ago. Nature, 547, 306-310.

Darman, F. (2017). Realitas Sejarah dalam Sastra Lisan Kapata Perang Kapahaha Desa Morella, Pulau Ambon. Kapata Arkeologi, 13(2), 131-140.

Dickerson, R. E. (1928). Distribution of life in the Philippines. Manila: Bureau of Printing.

Duija, I. N. (2005). Tradisi Lisan, Naskah, dan Sejarah. Wacana, 7(2), 111-124.

Endraswara, S. (2013). Folklor Nusantara. Yogyakarta: Ombak.

Fauzi, M. R., \& Simanjuntak, T. (2016). Sumatra and Its Problematics in The History of Human Migration to The Archipelago. In T. Simanjuntak (Ed.), Harimau Cave and The Long Journey of Oku Civilization (pp. 18-39). Yogyakarta: Gadjah Mada University Press.

Handoko, W. (2006). Penelitian Pendahuluan Gua-Gua Tamilou Kecamatan Amahai, Kabupaten Seram Bagian Timur. Berita Penelitian Arkeologi Maluku Dan Maluku Utara, 2(3), 18-36.

Handoko, W. (2007a). Asal-Usul Masyarakat Maluku, Budaya dan Persebarannya: Kajian Arkeologi dan Mitologi. Kapata Arkeologi, 3(5), 1-27.

Handoko, W. (2007b). Mitos Sahulau dan Pengungkapan Data Arkeologis, Survey Pendahuluan di Wilayah Bekas Kerajaan Sahulau. Ambon: Laporan Penelitian Arkeologi Balai Arkeologi Ambon.

Harisusanto, T. (1999). Bangunan Teras Berundak Masa Majapahit Abad XIV-XVI, suatu kajian arsitektural. Thesis Universitas Indonesia.

Heekeren, H. R. van. (1972). The Stone Age of Indonesia. Leiden: The Hague Martinus Nijhoff.

Hendrayana, H. (2013). Hidrogeologi Mata Air. Yogyakarta.

Intan, F. S., \& Istari, R. T. M. (1996). Laporan Penelitian Arkeologi Bidang Arkeometri. Geologi dan Arkeologi Situs Gua Kepulauan Kei Kecil, Kabupaten Maluku Tenggara, Propinsi Maluku. Jakarta: Pusat Penelitian dan Pengembangan Arkeologi Nasional.

Jacob, T. (2008). Ras, Etnik, dan Bangsa dalam Arkeologi Indonesia. Pertemuan Ilmiah Arkelogi IX, 2-3. Jakarta: Ikatan Ahli Arkeologi Indonesia.

Jatmiko, \& Mujabuddawat, M. Al. (2016). Jejak Budaya Paleolitik di Pulau Seram: Kajian Migrasi Manusia Awal di Wilayah Indonesia Timur. Kapata Arkeologi, 12(1), 71-78.

Kaharudin, H. A. F., Alifah, A., Ramadhan, L., \& Kealy, S. (2020). A review of archaeological dating efforts at cave and rockshelter sites in the Indonesian Archipelago. Journal of Indo-Pacific Archaeology, 44(0), 80-112.

Kealy, S., Louys, J., \& O'Connor, S. (2018). Least-cost pathway models indicate northern human dispersal from Sunda to Sahul. Journal of Human Evolution, 125, 5970.

Kealy, S., Wattimena, L., \& O’Connor, S. (2018). A Geological and Spatial Approach to Prehistoric Archaeological Surveys on Small Islands: Case Studies from Maluku Barat Daya, Indonesia. Kapata Arkeologi, 14(1), 1-14.

Kodoatie, R. J. (2012). Tata Ruang Air Tanah. Yogyakarta: C.V. Andi Offset.

Lape, P. Van. (2000). Contact and Conflict in the Banda Islands, Eastern Indonesia, 11th-17th Centuries. Unpublished $\mathrm{PhD}$ thesis, Brown University. Rhode Island.

Lape, P. Van, Aziz, F. A., Ekowati, D., Huff, J., Handoko, W., Huwae, A., \& Zenobi, L. (2017). Reframing the Island Southeast Asian Neolithic: Local vs regional adaptations. In B. Prasetyo, T. S. Nastiti, \& T. Simanjuntak (Eds.), Austronesian Diaspora: A New Perspective (pp. 65-76). Yogyakarta: Gadjah Mada University Press.

Latinis, D. K. (2015). The development of subsistence system models for Island Southeast Asia and Near Oceania: The nature and role of arboriculture and arboreal-based economies. World Archaeology, 32(1), 41-67.

Latinis, D. K., \& Stark, K. (2005). Cave Use Variability in Central Maluku, Eastern Indonesia. Asian Perspectives, 44(1), 119-136.

Leihitu, I., \& Permana, R. C. E. (2019). A Reflection of Painting Tradition and Culture of the Austronesian Based on the Rock Art in Misool, Raja Ampat, West Papua. Journal of Southeast Asian Studies, 24(1), 220-242.

Mansyur, S. (2007). Kajian Awal Fungsi Gua dan Wilayah Sebaran Situs Gua di Maluku dan Maluku Utara. Kapata Arkeologi, 3(5), 49-71.

Mansyur, S. (2016). Pengaruh Megalitik di Situs-situs Pertahanan Tradisional Masa Kolonial Awal di Maluku. Berkala Arkeologi, 36(2), 173-193.

Mujabuddawat, M. Al. (2015). Kejayaan Kesultanan Buton Abad ke-17 \& 18 dalam Tinjauan Arkeologi Ekologi. Kapata Arkeologi, 11(1), 21-32.

Mujabuddawat, M. Al. (2018). Laporan Penelitian Arkeologi, 
Menelusuri Jejak Benteng Tradisional di Pulau Seram dan Ambon Lease. Ambon: Balai Arkeologi Ambon.

Mujabuddawat, M. Al. (2019a). Menelusuri Jejak Permukiman dan Hunian Kuno di Kawasan Taman Nasional Manusela, Pulau Seram. Ambon: Laporan Penelitian Arkeologi Balai Arkeologi Maluku.

Mujabuddawat, M. Al. (2019b). Rekonstruksi Permukiman Kuno dan Penelusuran Data Terkini di Jazirah Huamual, Seram Barat. Ambon: LPA Balai Arkeologi Maluku.

Mujabuddawat, M. Al. (2020). Rekonstruksi Teori Penghunian dan Kronologi Jejak Permukiman Paling Awal di Kepulauan Maluku Bagian Selatan. In Memindai Peradaban di Maluku Buku Persembahan 25 Tahun Balai Arkeologi Maluku (pp. 79-144). Jakarta: Yayasan Pustaka Obor Indonesia dan Balai Arkeologi Maluku.

Mujabuddawat, M. Al, \& Peseletehaha, G. A. (2020). A Latest Discovery of Austronesian Rock Art in the North Peninsula of Buano Island, Maluku. Kapata Arkeologi, 16(1), 13-26.

Munandar, A. A. (1992). Gaya Arsitektur Bangunan Suci di Jawa Timur Abad X-XV Masehi. Jurnal Arkeologi Indonesia, 57-70.

Munandar, A. A. (1994). Beberapa Bukti Pemujaan terhadap Gunung dalam Masa Hindu-Buddha di Jawa. Depok: Universitas Indonesia.

Mundarjito. (1993). Pertimbangan Ekologi dalam Penempatan Situs Masa Hindu-Buda di Daerah Yogyakarta: Kajian Arkeologi-Ruang Skala Makro. Thesis Universitas Indonesia.

Nurani, I. A. (2000). Proses Migrasi Masa Prasejarah: Suatu Hipotesis Berdasarkan Kajian Lukisan Cadas di Indonesia Timur. In T. Simanjuntak (Ed.), Proceedings Evaluasi Hasil Penelitian Arkeologi: Bedugul, 14-17 Juli 2000. Bedugul: Pusat Penelitian dan Pengembangan Arkeologi Nasional.

O'Connor, S., Louys, J., Kealy, S., \& Mahirta. (2015). First Record of Painted Rock Art Near Kupang, West Timor, Indonesia, and the Origins and Distribution of The Austronesian Painting Tradition. Rock Art Research, 32(2), 193-201.

O'Connor, S., Spriggs, M., \& Veth, P. M. (2005). The Aru Island in Perspective. In O. Sue et.al (Ed.), The Archaeology of the Aru Island. Canberra: Pandanus Books.

Olson, S. (2004). Mapping Human History: Gen, Ras, dan Asal-Usul Manusia. Jakarta: PT. Serambi Ilmu Semesta.

Pritchard, J. K., Pickrell, J. K., \& Coop, G. (2010). The Genetics of Human Adaptation: Hard Sweeps, Soft Sweeps, and Polygenic Adaptation. Current Biology, 20(4), R208-R215.

Radiny, H. S., \& Artaria, M. D. (2019). Age and Tooth Wear of Ancient People in Lewoleba Site, East Nusa Tenggara, Indonesia. International Conference Postgraduate School Universitas Airlangga (ICPS 2019), 1-12. Surabaya: Universitas Airlangga.

Ririmasse, M. N. (2006). Jejak Tradisi Desa Maraina Wahai Seram Utara: Kajian Etnoarkeologi. Berita Penelitian Arkeologi, 2(3).

Ririmasse, M. N. (2010). Migrasi dalam Studi Arkeologi di Kepulauan Maluku: Sebuah Pengantar. Kapata Arkeologi, 6(11), 76-92.

Ririmasse, M. N. (2016a). Arkeologi Kawasan Hatusua di Seram Bagian Barat Maluku: Hasil Penelitian Terkini dan Arah Pengembangannya. Kapata Arkeologi, 12(2), 125-136.

Ririmasse, M. N. (2016b). Arkeologi Kepulauan Tanimbar Bagian Utara: Tinjauan Potensi di Pulau Fordata dan Pulau Larat Maluku Indonesia. Kapata Arkeologi, 12(1), 43-58.

Ririmasse, M. N., \& Handoko, W. (2009). Survei Arkeologi
Prasejarah di Wahai, Seram Utara. Ambon: Laporan Penelitian Arkeologi Balai Arkeologi Ambon.

Röder, J. (1938). Felsbilder auf Ceram. Paideuma, 1(1), 19-28.

Sahusilawane, F. (2005). Cerita-cerita Tua Berlatar Belakang Sejarah dari Pulau Seram. Ambon: Balai Kajian Sejarah dan Nilai Tradinisional Provinsi Maluku dan Maluku Utara.

Schull, William J. (1990). Introduction: The place and the study. In W. J. Schull \& F. Rothhammer (Eds.), The Aymara: Strategies in Human Adaptation to a Rigorous Environment (pp. 1-18). Dordrecht: Kluwer Academic Publishers.

Sedyawati, E. (1996). Kedudukan Tradisi Lisan dalam Ilmuilmu Sosial dan Ilmu-Ilmu Budaya. Warta ATL, Jurnal Pengetahuan Dan Komunikasi Peneliti Dan Pemerhati Tradisi Lisan.

Simanjuntak, T. (1997). Akhir Plestosen dan Awal Holosen di Nusantara. Proceedings PIA VII, Jilid 2. Jakarta: Pusat Penelitian dan Pengembangan Arkeologi Nasional.

Simanjuntak, T. (2000). Perspektif Global Prasejarah Indonesia Proceedings Evaluasi Hasil Penelitian Arkeologi: Bedugul, 14-17 Juli 2000. Bedugul: Pusat Penelitian dan Pengembangan Arkeologi Nasional.

Simanjuntak, T., Forestier, H., Driwantoro, D., \& Jatmiko. (2006). Daerah Kaki Gunung: Zaman Batu. In D. Guillaud (Ed.), Menyusuri Sungai, Merunut Waktu: Penelitian Arkeologi di Sumatera Selatan. Jakarta: PT. Enrique Indonesia.

Simanjuntak, T., Pojoh, I. H. E., \& Hisyam, M. (2006). Austronesian Diaspora and the Ethnogeneses of the People in Indonesian Archipelago. Jakarta: LIPI Press.

Smith, M., Spriggs, M., \& Frankhauser, B. (1993). Sahul in Review. Canberra: Department of Prehistory, Research School of Pacific Studies.

Soegondho, S. (1994). Laporan Hasil Penelitian Arkeologi Bidang Prasejarah, Survei Kepulauan Maluku (Seram dan Ambon). Jakarta: Pusat Penelitian dan Pengembangan Arkeologi Nasional.

Spriggs, M. (1990). Archaeological and ethnohistorical research in Maluku 1975 and 1977: an unfinished story. Cakalele, 1(1/2).

Spriggs, M. (1997). The Island Melanesians. Oxford: Blackwell Publishers Ltd.

Spriggs, M., \& Miller, D. (1988). A Previously Unreported Bronze Kettledrum from the Kai Islands, Eastern Indonesia. Indo-Pacific Prehistory Association Bulletin, 8, 79-89.

Stark, K., \& Latinis, D. K. (1992). The Archaeology of Sago Economies in Central Maluku: An Initial Sketch. Cakalele, 3, 69-86.

Stark, K., \& Latinis, D. K. (1996). The Response of Early Ambonese Foragers to the Maluku Spice Trade: The Archaeological Evidence. Cakalele, 7, 51-76.

Sudarmika, G. M., \& Handoko, W. (2007). Kerajaan Sahulau: Melacak Fragmen Sejarah Yang Hilang, Potret Sejarah, Tutur dan Arkeologi. Kapata Arkeologi, 3(4), 50-73.

Sugiyanto, B. (2006). Masalah Pelestarian Gua-gua Penguburan di Kabupaten Tabalong, Kalimantan Selatan. Naditira Widya, (16).

Supriatna, J. (2014). Berwisata Alam di Taman Nasional. Jakarta: Yayasan Pustaka Obor.

Suroto, H. (2010). Prasejarah Papua. Denpasar: Udayana University Press.

Tan, N. (2014). Rock Art Research in Southeast Asia: A Synthesis. Arts, 3(1), 73-104.

Tanudirjo, D. A. (2011). Interaksi Austronesia-Melanesia Kajian Interpretasi Teoritis. In M. I. Mahmud \& E. N. I. Djami (Eds.), Austronesia dan Melanesia di Nusantara (pp. 23-42). Jakarta: Penerbit Ombak.

Triwuryani. (1995). Alokasi Situs-situs Arkeologi di Kawasan 
Das Way Sekampung. Seminar Manusia Dalam Ruang Studi Kawasan Arkeologi. Yogyakarta: Pusat Penelitian dan Pengembangan Arkeologi Nasional.

Undaharta, N. K. E., Sutomo, Ardaka, M., \& Tirta, I. G. (2012). Autekologi Begonia di Sebagian Kawasan Taman Nasional Manusela, Maluku. Jurnal Penelitian Hutan Dan Konservasi Alam, 9(1), 1-11.

Veth, P. M., O’Connor, S., Spriggs, M., Nayati, W., Jatmiko, A., \& Husni, M. (2005). The Ujir Site: An Early Historic Maritime Settlement in Northwestern Aru. The Archaeology of the Aru Islands, Eastern Indonesia. Terra Australis, 22, 85-93.

Wattimena, L. (2016a). Batu Teong di Pegunungan Kota Ambon, Kepulauan Ambon Lease. Kapata Arkeologi, 12(2), 213-220.

Wattimena, L. (2016b). Penelitian Arkeologi Prasejarah Kampung-kampung Tua di Pulau Ambon dan Lease, Propinsi Maluku. Ambon: Laporan Penelitian Arkeologi Balai Arkeologi Ambon.

Wattimena, L., \& Handoko, W. (2012). Hunian Prasejarah di Jasirah Leihitu Pulau Ambon, Maluku. Kapata Arkeologi, $8(2), 51-58$.

Wattimena, L., Nussy, M., \& Ferdinandus, S. (2019). Tinjauan Kasus Temuan Gambar Cadas di Bukit Hatupatola Seram Barat. Ambon: Balai Arkeologi Ambon.

Widianto, H. (2008). Human Arrival and Its Dispersal during The Holocene in Sulawesi. In T. Simanjuntak (Ed.), Austronesian in Sulawesi (pp. 23-32). Galang Press.

Widianto, H., Arifin, K., Permana, R. C. E., Setiawan, P., Said, A. M., \& Oktaviana, A. A. (2017). Gambar Cadas Prasejarah di Indonesia. Jakarta: Direktorat Pelestarian Cagar Budaya dan Permuseuman, Kementerian Pendidikan dan Kebudayaan.

Wohlwill, J. F. (1974). Human Adaptation to Levels of Environmental Stimulation. Human Ecology, 2(2), 127 147.

Zoetmulder, P. J. (1982). Old Javanese-English Dictionary II. Gravenhage: Martinus Nijhoff. 